\title{
NEW ANCIENT NORTH ARABIAN INSCRIPTIONS FROM ĠADĪR AL-AHMAR IN AL-ȘAFĀWİ REGION, NORTHEASTERN JORDANIAN BADIYA
}

\author{
HUSSEIN M. AL-QUDRAH \\ The Hashemite University, Queen Rania Institute of Tourism and Heritage \\ P.O. Box 150450, Zarqa 13115, Jordan \\ e-mail: hus_alqudrah@yahoo.com; hqudrah@hu.edu.jo
}

This essay is an analytical study of sixteen new Ancient North Arabian inscriptions collected by the author during an epigraphical survey in 2010 in the area of Ġadīr Al-Aḥmar in Al-Ṣafāwī Region Northeast Jordan. On the grounds of the shape of script and the language, these inscriptions are classified as Safaitic. The script was known in the region to the south and southeast of Damascus (including north and northeast of Jordan) and in north and northwest Saudi Arabia.

The goal of this analysis is to study the inscriptions, the semantics and morphology of the words and the proper nouns contained therein. Furthermore, the paper also identifies certain new vocabulary items, such as four personal names mentioned for the first time in the corpus of the Safaitic inscriptions.

Key words: Ancient North Arabia, Jordan, basinscriptions, Safaitic, Gadīr Al-Aḥmar.

\section{Introduction}

Gadīr Al-Ahmmar is a site located approximately $20 \mathrm{kms}$ to the east of Al-Ṣafāwī town on the highway road to Baghdad. The site is located at the latitude and longitude coordinates $32^{\circ} 07^{\prime} 54^{\prime} .5232$ north and $37^{\circ} 21^{\prime} 53^{\prime} .1157$ east.

Many Safaitic inscriptions are carved on basalt stone surfaces, and spread on both sides of a valley called al- ${ }^{\mathrm{c}}$ Awsajī in al-Safâwī region. Our inscriptions, the subject of this study, were collected from Gadīr al-Ahmar which is a branch of the valley. The scholars agree on dating the Safaitic inscriptions from the 1st century BC to the 4th century AD.

The tribally organised people who produced these inscriptions adapted the Ancient South Arabian script (known in Arabic as al-musnad). This fact reinforced the idea that the old North Arabian tribes emigrated from South Arabia to the North. 
Although these tribes living in Al-Harrah are considered to have been pastoralists, they were literate and left inscriptions such as these. This underlines the fact that they had been a sedentarised people before coming to this area.

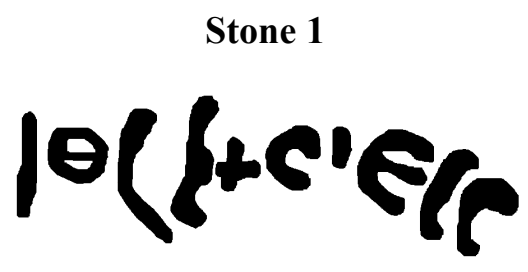

\section{Inscription No. 1}

Transcription: 1 wrdt bn hirb.

Translation: By Wrdt son of Hrrb.

Wrdt: p.n. m. unrecorded previously in this form either in Safaitic or in other Semitic inscriptions. The name occurred in Safaitic in the forms $w r d$, wrdn and wrd'l (Harding 1971, p. 640), wrd in Thamudic (Branden 1950, p. 528), and $w r d$ in Sabaic (CIH 204/4). In Arabic ورد / ward is the lion (Ibn Durayd 1991, p. 279).

Ḥrb: p.n. m. frequently attested in Safaitic, Thamudic, Lihyanite, Sabaic, Minaean and in Qatabanian (Ababneh 2005, Nos 88, 98, 379; Rawan 2013, Nos 102, 107, 286; Hayajneh 1998, p. 118; Abu al-Hasan 1997, p. 428). It is the equivalent of the Arabic حرب / harb 'war'; name derived from the root hrb 'to fight' (Ibn Durayd 1991, p. 75).

\section{Stone 2}

This stone contains three inscriptions (Nos 2, 3, 4).

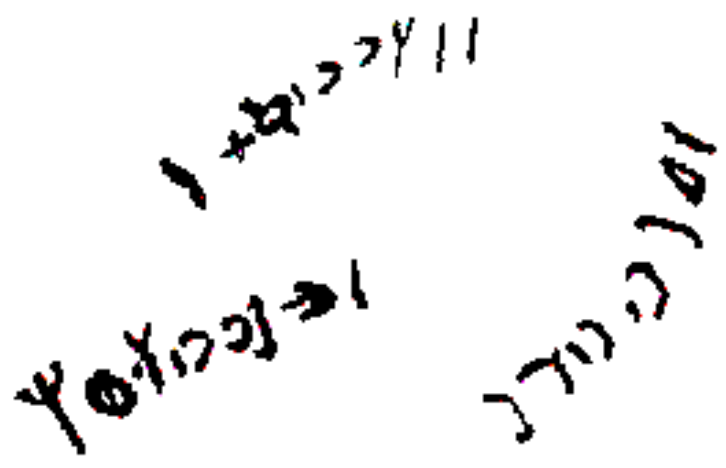




\section{Inscription No. 2}

Transcription: $1 \mathrm{hrb} b \mathrm{bn} \mathrm{h}^{\mathrm{c}} \mathrm{w} \underline{\mathrm{d}}$.

Translation: By Hrb son of $\mathrm{H}^{\prime} w \underline{d}$.

Hrb: see inscription No. 1 above.

$\dot{\mathbf{H}}^{\mathbf{c}} \mathbf{w d}$ : p.n. m. consists of the definite article $h$ and the name ${ }^{c} w \underline{d}$, this form of personal name being assimilated regularly in Safaitic (Harding 1971, p. 618; Ababneh 2005, Nos 56, 206, 708). The parallel form $h^{c} \underline{d}$ is attested in Minaean (al-Said 1995, p. 172).

The Safaitic inscriptions recorded relevant forms such as ${ }^{c} w \underline{d}$ (al-Theeb 2000a, p. 122; Maani 2011, p. 160), ${ }^{c} w \underline{d n}$ (Rawan 2013, Nos 214, 334), in addition to the form ${ }^{c} \underline{d}$ that was mentioned in Safaitic, Thamudic and in Lihyanite (Jamme 1967, p. 92; Harding 1971, p. 411). Ancient South Arabian inscriptions show a parallel form ${ }^{c} w \underline{d}^{m}$ in Sabaic (Byn M1/ 1 in CSAI ${ }^{1}$ ) and in Ḥaḍramitic (Jamme 1963, No. 962/1).

\section{Inscription No. 3}

Transcription: 1 lhb bn qtl.

Translation: By Lhb son of Qtl.

Lhb: p.n. m. attested in Safaitic (Harding 1971, p. 521; Ababneh 2005, No. 345), and Lhbt (Ababneh 2005, Nos 537, 706), and in Thamudic faclān form (Branden 1950, p. 533). It is equivalent to the Arabic name لَهَب / Lahab 'flame, blaze' (Ibn Durayd 1991, p. 491).

Qtl: p.n. m. frequently attested in Safaitic (Harding 1971, p. 476; Ababneh 2005, Nos 481, 1126; Rawan 2013, No. 84), in contrast, it rarely appeared in Thamudic; it has one evidence (Winnett and Reed 1973, p. 92); name derived from the root $q-t-l$ of the verb and noun ('killed, homicidal, murderous'), frequently found in Ancient North Arabian inscriptions and in Classical Arabic (Ibn Manẓūr 2003: $q t l)$.

\section{Inscription No. 4}

Transcription: 1 ğrbn bn sr.

Translation: By Ğrbn son of Sr.

Ğrbn: p.n. m. frequently attested in Safaitic (Winnett-Harding 1978, No. 219²; Ababneh 2005, No. 139). It could be vocalised as ğarbān 'mangy, scabby', another relevant form $\breve{G r b b}$ (CIS 4816) could be treated as a derivation of the same root. The identical pattern $\breve{G r b n}$ is attested in Early Sabaic inscriptions (RES 4640),

\footnotetext{
${ }^{1}$ CSAI: Corpus of South Arabian Inscriptions = http://csai.humnet.unipi.it/csai/html/

2 The inscription was read by the authors as: 1 gr bn bnșrḥn bn rkb bn mdr w.... . But the correct reading as it is shown in the inscription is: 1 grbn bn șrḥn bn rkb bn mạr w....
} 
and there are pieces of evidence of the form $\breve{G r b y n}$ as a personal name in Qatabanian, and as clan/family name in Sabaean (Abdallah 1975, p. 39), it has also been recorded as a second name in Hadrami inscription (Frantsouzoff 1995, p. 18). Further connected indications are in the Minaean inscriptions which show $\underline{d}-\breve{g} r b$ as a theonym (Avanzini 1995, p. 103-104) and as a god epithet (Arbach-Schiettecatte 2006, pp. 24, 49).

Sr: p.n. m. well known in Safaitic and Thamudic (Harding 1971, p. 315; Ababneh 2005, Nos 82, 139, 290; Rawan 2013, Nos 105, 212, 221; Branden 1950, p. 539), and in Lihyanite (Abū al-Hasan 2002, No. 269). It is equivalent to the Arabic name سور / Sūr (Ibn Durayd 1991, p. 293).

The hollow $-w$ - swr (Clark 1980, No. 372) could be considered as a various spelling of the name $s r$ in Safaitic. In Sabaic it occurs as a second position in the compound name $s d q / s^{l} r$ (RES 3088).

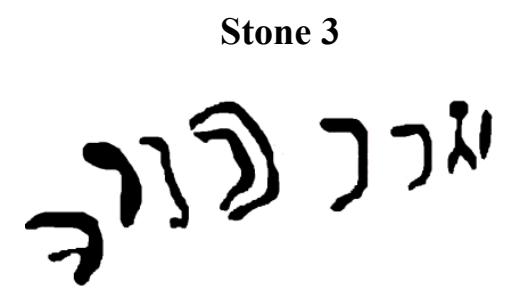

\section{Inscription No. 5}

Transcription: 1 șb bn mrbḥ.

Translation: By Șb son of Mrbḥ.

Șb: p.n. m. frequently attested in Safaitic (Harding 1971, p. 365), and in Thamudic (al-Said 2004, No. 6), and in Haḍramitic (Jamme 1963, No. Ja 982/2). It is equivalent to the Arabic name صنَب / șabb 'full of love' (Ibn Durayd 1991, p. 423).

Mrbh: p.n. m. It is derived from the root $r-b-h$ in the form $m f^{c} l$ 'gainful'. It is attested in Safaitic (Harding 1971, p. 537). The form rbh is recorded in Thamudic (Jamme 1967, p. 94), in Lihyanite (Abū al-Hasan 1997, p. 429), and in Qatabanian (Hayajneh 1998, p. 146), rbh ${ }^{m}$ in Sabaic (Tairan 1992, p. 123) and in Qatabanian (Hayajneh 1998, p. 147). The compound personal name $r b h^{c} l l$ is mentioned in the Minaean inscriptions (Arbach-Schiettecatte-al-Hādī 2008, p. 83). 


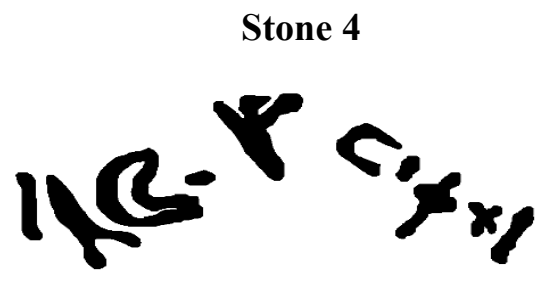

Inscription No. 6

Transcription: $1 \mathrm{hm}^{\mathrm{c}} \underline{\mathrm{d}}$ bn qtl.

Translation: By $\mathrm{Hm}^{\mathrm{c}} \underline{\mathrm{d}}$ son of Qtl.

$\mathbf{H m}^{\mathbf{c}} \mathbf{d}$ : p.n. m. attested in Safaitic (Harding 1971, p. 624; Ababneh 2005, No. 605). The name consists of two elements: the definite article $h$ - and the name $m^{c} d$ which is equivalent to the Arabic name sعاذ / $M u^{c} \bar{a} \underline{d}$. It is mentioned as $M^{c} \underline{d}$ in Safaitic (Ababneh 2005, No. 286), Thamudic and in Lihyanite (Harding 1971, p. 553).

qtl: see inscription No. 3 above.

\section{Stone 5}

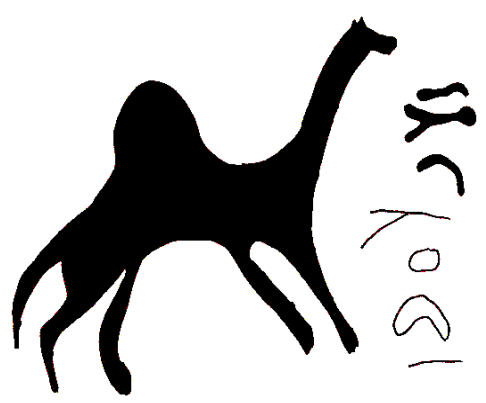

\section{Inscription No. 7}

Transcription: 1 șb hğml.

Translation: This camel is for $\mathrm{Sb}$.

Șb: see inscription No. 5 .

h̆ğml: n. s. m. frequently attested in Safaitic and in Ancient North Arabian inscriptions (Corbett 2010, p. 427). 


\section{Stone 6}

This stone contains two inscriptions (Nos 8, 9).

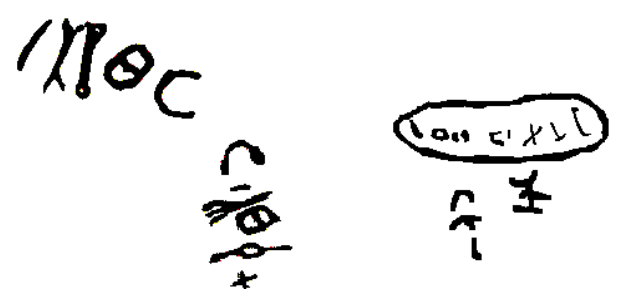

Inscription No. 8

Transcription: 1 'twb bn dwqt.

Translation: By 'twb son of Dwqt.

'twb: p.n. m. well known in Safaitic (Harding 1971, p. 21) and Thamudic (Branden 1956, p. 175), the name is in $a f^{c}$ al form from the root $t-w-b$ 'revert'. It is attested as $\underline{t} w b$ in Sabaic (Jamme 1956, No. Ja 467/1) and in Qatabanian (Hayajneh 1998, p. 288). The theophoric compound form $\underline{t} b l h$ is mentioned in Lihyanite (Abū al-Hasan 1997, No. 119; 2002, No. 234), and $\underline{t} b$ 'l in Sabaic (Tairan 1992, p. 90).

Dwqt: p.n. m. it is derived from the hollow root $\underline{d}-w-q$ with a common meaning 'taste', in addition it has a sense of 'holding up the lance, and aiming by the bow at something' (al-Himyarī 1999, p. 2315; al-Zabīdī 1994: $\underline{d} w q$ ). The root occurred in Safaitic as a verb and can be interpreted in the light of the Arabic data as 'to die' (Sadaqah-Harahsheh 2005, p. 58). Another instance: l 'ndt bn nms w nğwt $m$ blt $w r^{c} y t \underline{d} q l m[n]$ 'hlk hmsfr (CIS 1781) ${ }^{3}$ could illuminate this view. Therefore this personal name has a sense of 'the death'. - It is hitherto unrecorded in Safaitic in this form, but it has been attested as $\underline{d} w q$ (Harding 1971, p. 260), $\underline{d} q$ in Thamudic (Branden 1956, p. 177), and $\underline{d} q^{m}$ in Qatabanian (Hayajneh 1998, p. 140).

\section{Inscription No. 9}

Transcription: lğnn bn hzzr.

Translation: By Ğnn son of Huzr.

Ğnn: p.n. m. attested in Safaitic (Harding 1971, p. 169; Ababneh 2005, Nos 216, 216a, 331; Rawan, No. 236) and Lihyanite (Abū al-Hasan 2002, No. 321). Thamudic

${ }^{3}$ For 'nḍt son of Nms, and he escaped from disaster "blm", and the death "dq" affected the heart who destroyed "'hlk" the inscription "hmsțr" with fright " $r$ 't". 
inscriptions show the forms ğnnt (al-Theeb 2000b, No. 76), ğnt (Branden 1950, p. 525) and $\breve{g} n$ (Maani-Kareem 2001, No. 17), in Qatabanian $m \breve{g} n^{m}$ (Hayajneh 1998, p. 230).

Hzr: p.n. m. attested in Safaitic (Harding 1971, p. 220; Ababneh 2005, Nos 197, 707, 988). Thamudic inscriptions consist of this name (Maani and Kareem 2001, / خازر No. 12). It is the equivalent of the well-known Arabic personal name Ḩāzar 'narrow-eyed'.

\section{Stone 7}

\section{$1 \cdot p \cos \theta t$}

Inscription No. 10

Transcription: $1^{\mathrm{c}} \mathrm{d}$ bn wtq.

Translation: By ${ }^{\mathrm{c}} \mathrm{d}$ son of Wtq.

'd : p.n. m. frequently attested in Safaitic, Thamudic (Harding 1971, pp. 408-409; alTheeb 2000b, No. 113; al-Said 2004, No. 2), as well as the form ${ }^{c} d d$ (Ababneh 2005, Nos 778, 779), the Minaean inscriptions contain both of ${ }^{c} d$ (Harding 1971, p. 409) and ${ }^{c} d t$ (al-Said 1995, p. 135), ${ }^{c} y d^{m}$ in Qatabanian (Hayajneh 1998, p. 205). It is also mentioned as a theophoric personal name ${ }^{c} d ' l$ in Sabaic (Tairan 1992, p. 155) and in Minaean (al-Said 1995, p. 135).

Wtqq: p.n. m. attested in Safaitic (Harding 1971, p. 635). It is equivalent to the common Arabic personal name واثث / Wātiq 'confident'.

\section{Stone 8}

This stone contains two inscriptions (Nos 11, 12).

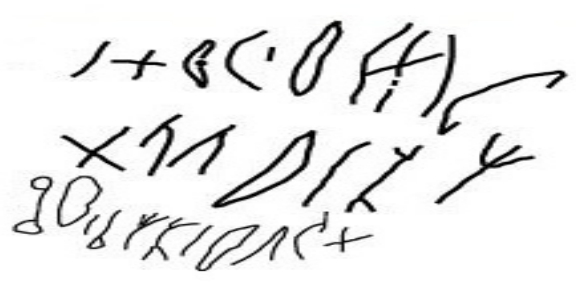


Inscription No. 11

Transcription: ltm bn mțr $\underline{\mathrm{d}}$ 'l mskt.

Translation: By Tm son of Mțr of the tribe Mskt.

Tm: p.n. m. it is a common name in the pre-Islamic Arabic inscriptions. Harding (1971, p. 136) compared it with the Arabic Tamm 'be completed'. It could also be the equivalent of the Arabic Taym 'servant' (Ibn Manzūr 2003: tmm).

Mțr: p.n. m. the name is probably derived from the conditions surrounding a child's birth. It is well known in Safaitic (Harding 1971, p. 551; Rawan 2013, Nos 128, 129, 245), and in Thamudic (al-Theeb 2000b, No. 94; King 1990, p. 549), $m t r$ and bnmtr in Lihyanite (Abū al-Hasan 2002, Nos 200, 310), mtrrw and mtyrw in Nabataean (Negev 1991, p. 43), and mtrn in Sabaic (RES 4546/1). The name is equivalent to the Arabic name Matar 'rain' (Caskel 1966, p. 404).

d'I: It is a pronominal adjective preceding names of tribes, clans or subtribes, which means 'of the tribe X'; it consists of the particle $\underline{d}$ and the substantive noun ' $l$ 'family, tribe'.

It is well known in Safaitic (Macdonald 2004, p. 508; al-Theeb 2003, Nos 1, 2, 26) and Thamudic (King 1990, Nos KJA 36, KJC 42, 647). For more discussion, see Maani-Sadaqah (2003, p. 644-645).

Mskt: a tribal name. It is a well-known tribe that appears in Safaitic inscriptions (see al-Rousan 1987, pp. 256-257).

\section{Inscription No. 12}

Transcription: tmny d'l mskt.

Translation: Tmny of the tribe Mskt.

Tmny: p.n. m. from the root $\underline{t}-m-n$ 'the eighth or precious, valuable'. This form is unattested in Safaitic, but we find the form mtmn (Ababneh 2005, Nos 931, 977). However, such ending $-y$ is found in other Safaitic names such as grmy, hny (Ababneh 2005, Nos 19, 264), wtry and ${ }^{c} b d y$ (Clark 1980, Nos 167, 734).

Mskt: see inscription No. 11 above.

\section{Stone 9}

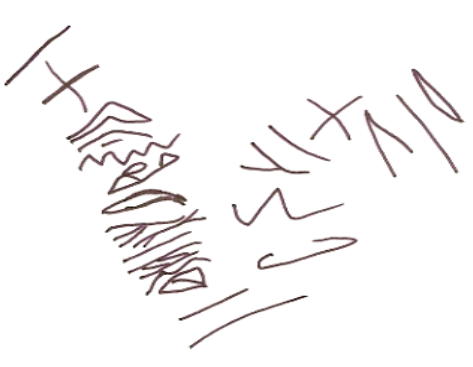




\section{Inscription No. 13}

Transcription: ltm bn šctm d'l df wPyr fhlt slm.

Translation: By Tm son of $\breve{S}^{c}$ pm of the tribe $-f$ and he returned back, Oh Allat (grant) peace.

Tm: see inscription No. 11 above.

$\breve{\mathbf{S}}^{\mathbf{t}} \mathbf{m}$ : p.n. m. attested in Safaitic (Harding 1971, p. 350; Rawan 2013, No. 324), in Minaean (al-Said 1995, p. 124), in Sabaic (Harding 1971, p. 350) and in Haḍramitic (Pirenne 1975, Khor Rori 3/1). - This name is suffixed with $-m$ which rarely occurred in Safaitic inscriptions, e.g. $-m$ can be detected in names like 'blm (CIS 4227, 4831), 'hym (Winnett-Harding 1978, No. 3000), and glhm (Winnett-Harding 1978, Nos 2673, 2773). But the suffixation with $-m$ is well known in Ancient South Arabian names such as 's ${ }^{1} \mathrm{lbm}$, 's ${ }^{1} \mathrm{lmm}$, șlhm (see Hayajneh 1998 , pp. 20, 70, 180). Furthermore, the same phenomenon can be observed in the traditional Arabic name such as Zurqum. Therefore, the Safaitic name, $\check{s}^{c} p m$, could be compared with the traditional Arabic name $\breve{S} a^{c} p a m$ (Ibn Durayd 1991, p. 349), the name is derived from the root which means 'become shaggy or untidy, or become defiled with dust' (al-Zabīdī 1994: $\check{s}^{c} \underline{t}$ ).

d'l: see inscription No. 11 above.

Df: It is a well-known tribal name in Safaitic (Harding 1969, p. 12; Winnett-Harding 1978 , p. 627). It is one of the biggest Safaitic tribes in the Harra region southeast of Damascus (al-Rousan 1987, pp. 328-329). The inscriptions show the importance of this tribe that for a while lived together with other tribes such as the ' $w \underline{d}$ which played a decisive role in strengthening the Arab tribes' opposition to the Nabataean kingdom. They forced the Nabataeans to fight against them (CIS 2446 in Macdonald 2000, p. 51; Sadaqah 2013, p. 146).

wPyr: w-: conjunction 'and'. Pyr: v. pft. + suff 3p. s. m. from the root Pyr 'return, come’ (Ibn Manzūur 2003: syr).

f-h-lt: $\boldsymbol{f}$-: conjunction 'and'. -h-: It is used to express a vocative case in Safaitic inscriptions. lt: It is a well-known divine name in the North Arabian inscriptions.

sIm: It is a common Semitic noun 'peace, welfare' (Beeston et al. 1982, p. 126; Hoftijzer-Jongeling 1995, pp. 1146-1152; al-Zabīdī 1994: slm). It is a part of invocation mood in Safaitic inscriptions denoting the peaceful manner that occurred, and to whom the good deeds are performed, i.e. asking $d \check{s} r$ the safety (for their body and property) after conducting the raid. It can be pointed out also in Thamudic (al-Theeb 2002, No. 75). 


\section{Stone 10}

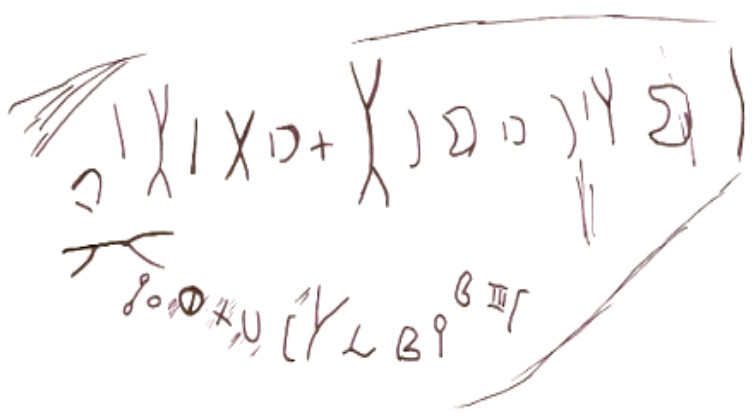

\section{Inscription No. 14}

Transcription: [l] mhr bn mr't bn hl'l bn 't $\underline{\mathrm{c}}^{\mathrm{c}} \mathrm{wtzr}$ hsmy mț.

Transcription: [By] Mhr son of Mr't son of Hl'l son of ' $\underline{t}^{\mathrm{c}}$, and he watched the sky for rain.

Mhr: p.n. m. attested in Safaitic (Ababneh 2005, No. 742) and in Thamudic (Branden 1956, p. 47) in addition to feminine $-t$ form ending (Branden 1956, p. 129), in Qatabanian (Hayajneh 1998, p. 241), in Minaean $\underline{d}-m h r$ (RES 3849/2). It is attested in Lihyahite with feminine $-h$ ending $m h r h$ (Abū al-Ḥasan 1997, No. 5/1). It could be vocalised as Mohr 'pony'.

Mr't: p.n. m. attested in Safaitic (see: Ababneh 2005, Nos 121, 832), in Thamudic (Branden 1956, pp. 96, 109), in Nabataean (Negev 1991, p. 41). However, the feminine forms $m r^{\prime} t$ is attested in Qatabanian (Hayajneh 1998, p. 231) and Minaean inscriptions (RES 2773), and $m r^{\prime} h$ in Lihyanite (Abū al-Hasan 1997, No. 50/1).

HI'l: a composite p.n. m. Well known in Safaitic and in Thamudic inscriptions (Harding 1971, p. 225; Rawan 2013, No. 108); it consists of two elements $h l$ 'friend' + the name of the god 'l (see Harahsheh 2001, No. 80).

't $\underline{\mathbf{c}}^{\mathbf{c}}$ p.n. m. well known in Safaitic in the meaning 'deliver, rescue' (Harding 1971, p. 20; Ababneh 2005, Nos 420,567, 850). The Arabic parallel name could be Ait $a^{c}$ (Caskel 1966, p. 149), and corresponded to the Greek I $\theta$ ans (Wuthnow 1930, p. 58).

wtzr: $\boldsymbol{w}$-: it is a common conjunction in Semitic 'and'. $\boldsymbol{t z} r$ : it is derived from $n-z-r$ 'on the look-out for, watched for' (al-Zabīdì 1994: $n z r$ ). This verb contains the dental nasal $-n-$. The frequent assimilation of $-n$ - to the following consonant reflects and confirms the weakness of this phoneme. Therefore, the studied verb here tends as: wa-intazara, wa-ittazara, wa-tazara. It is well known in Safaitic inscriptions (Littmann 1943, p. 13; Ababneh 2005, No. 101).

hsmy: $\boldsymbol{h}$-: definite article 'the'. smy: n. s. f. 'sky', common Semitic noun. mṭr: see inscription No. 11 above. 


\section{Stone 11}

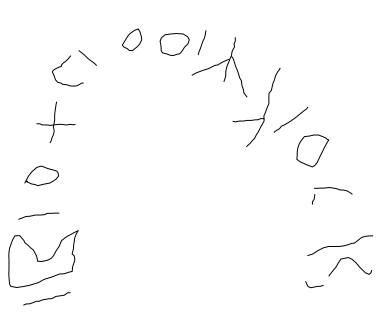

\section{Inscription No. 15}

Transcription: $1 \mathrm{mn}^{\mathrm{c}} \mathrm{t}$ bn ' ${ }^{\mathrm{g}} \mathrm{l} \underline{d}^{\prime} l \mathrm{~g} \mathrm{grm}$.

Translation: By $\mathrm{Mn}^{\mathrm{c}} \mathrm{t}$ son of ${ }^{\mathrm{c}} \breve{\mathrm{g} l}$ of the tribe Ğrm.

$\mathbf{M n}^{\mathrm{c}} \mathrm{t}$ : p.n. m. It is a masculine personal name with the feminine $-t$ ending, from the root $m-n-$ ', it means 'strong, keep from, fortify oneself, immune, invincible' (al-Zabīdi 1994: $m n^{c}$ ), therefore, it could be compared to the masculine tradition name $\operatorname{Mani}^{-c}$ (Caskel 1966, p. 398). It is attested in Safaitic (Clark 1980, No. 80) and in Thamudic (King 1990, p. 551).

' $\breve{g} \mathbf{l}:$ p.n. m. It is a masculine personal name from the $\operatorname{root}^{c}-\breve{g}-l$ and attaches to ${ }^{c} \breve{g} l$ a personal name in Arabic (Caskel 1966, p. 353). It is very probable that the name has the meaning of 'calf' (al-Himyarī 1999, vol. 7, p. 4379). This form ${ }^{c} \breve{g} l$ is mentioned in Safaitic (Winnett-Harding 1978, No. 2896), and in Thamudic (Branden 1956, No. Ph 266), ${ }^{c} \breve{g} l^{m}$ in Sabaic (Arbach 2002, p. 52), and in Qatabanian (Abdallah 1975, p. 76).

d'l: see inscription No. 11 above.

Ğrm: It is a Safaitic tribal name (Harding 1969, p. 8). It is also mentioned in Thamudic (Winnett-Reed 1970, No. 84) and in South Arabian inscriptions (Mikyash 1993, p. 38). The tribal form Grrm'l is also attested in Safaitic (Winnett-Harding 1978, p. 21). 


\section{Stone 12}

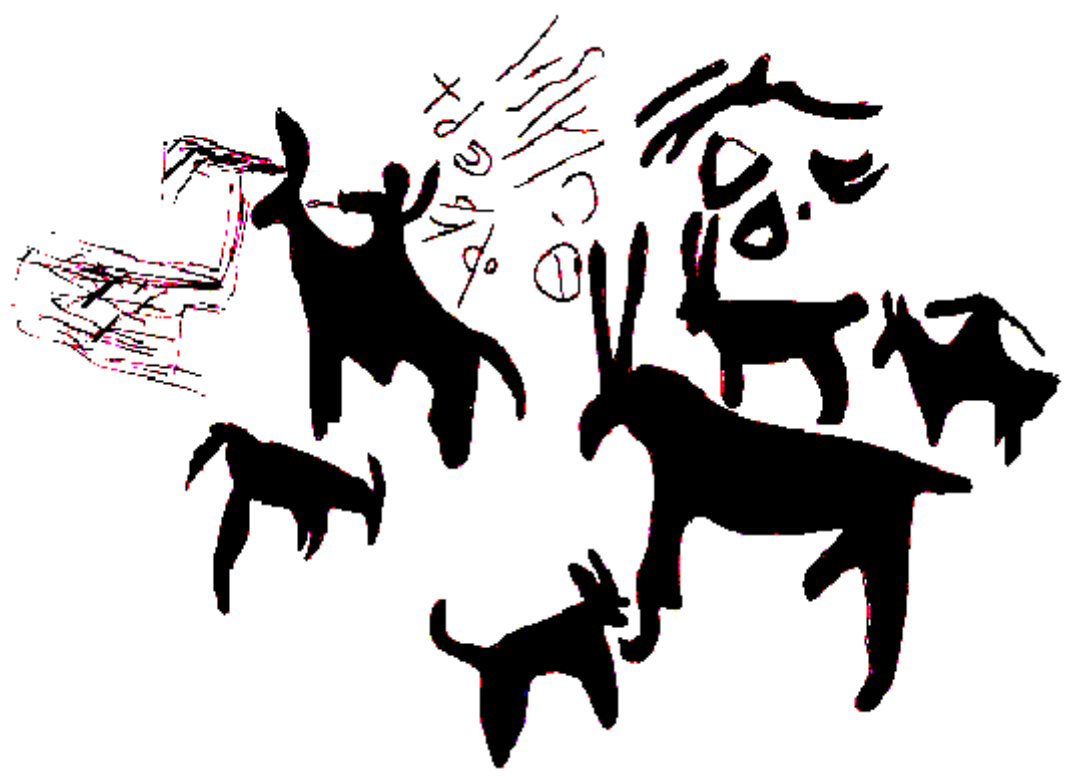

\section{Inscription No. 16}

Transcription: 1 nšl'l bn w $w^{c} d$ h-dmyt.

Translation: This picture is for Nšl' 1 son of $\mathrm{W}^{\mathrm{c}} \mathrm{d}$.

Nšl'l: p.n. m. It is a theophoric personal name that consists of $n s ̌ l$ and the divine element ' $l$. The name could be considered a nominal sentence. In view of this, the first element could be compared to the Classical Arabic al-našĭl 'thin, flimsy sword' (al-Zabīdī 1994: $n s ̌ l l)$, or as a verbal sentence in perfect tense and compared to našal 'extricated, get out, carry off' (al-Himyarī 1999, vol. 10, p. 6603). Therefore, this name can be interpreted as 'the sword of God' or 'God saved, extricated'. Thus, the name reflects God's ability to carry out good deed. It is recorded in Safaitic inscriptions (Hazim 1986, p. 124), and also attested as a personal name $n s ̌ l$ in Safaitic, Thamudic, Sabaean, Lihyanite and Nabataean (Sadaqah-Harahsheh 2005, No. 5; Ababneh 2005, Nos 72, 185, 917).

$\mathbf{W}^{\mathbf{c}} \mathbf{d}$ : p.n. $\mathrm{m}$. It is a masculine personal name from the root $w^{c}-d$. It is possible to equate it with the Classical Arabic noun $w \bar{a}^{c} i d$ 'good omen promise' (al-Himyarī 1999, vol. 11, p. 7218). It is attested in Safaitic (Winnett-Harding 1978, No. 1469) and in Thamudic (King 1990, p. 562; al-Theeb 2000a, No. 81).

h-dmyt: $\mathrm{n}$. m. It is a feminine noun preceded by the definite article $-h$, from the root $d-m-w / y$. It has many evidences in Safaitic (Ababneh 2005, No. 2). It can be compared to dumyat 'statue, picture' in Classical Arabic (al-Himyarī 1999, vol. 4, p. 2154). 


\title{
Conclusion
}

The majority of Safaitic inscriptions and rock drawings are found in the volcanic basalt region called Al-Harrah in northeastern Jordan. Archaeologists have found inscriptions recording pastoral activities such as grazing camels, goats and sheep and relate that they migrated or encamped or spent the spring or winter in a particular place.

This study aimed to publish sixteen new Ancient North Arabian inscriptions written in the so-called Safaitic script which had been explored by the author through a fieldwork survey in northeast Badiya of Jordan during the year 2010. These and other texts are often found in association with cairns which were sometimes built over graves.

The inscriptions present scenes of Safaitic everyday life and they yield precious information about linguistic phenomena and the variant forms of the Safaitic script. The vocabularies in the inscriptions were compared with their parallels in other old North Arabian inscriptions (such as Thamudic and Lihyanite) as well as in South Arabian ones (such as Sabaic, Minaean and Qatabanian).

The study recorded some common personal names, nouns, tribes, verbs and prepositions, in addition to some new proper personal names like $w r d t, \underline{d} w q t$, and $\underline{t} m n y$, and one new theophoric compound personal name $n s ̌ l ' l$.

\author{
Abbreviations \\ ADAJ Annual of the Department of Antiquities of Jordan. \\ CIH Corpus Inscriptionum Semiticarum. 1889-1932. \\ CIS Corpus Inscriptionum Semiticarum. 1951. \\ CSAI http://csai.humnet.unipi.it/csai/html/ \\ RES Répertoire d'Epigraphie Semitique publié la Commission du Corpus Inscriptionum Semiti- \\ carum.
}

\section{Bibliography}

Ababneh, M. (2005): Neue safaitische Inschriften und deren bildliche Darstellungen. Berlin, Shaker Verlag (Semitcia et Semitohamitica Berolinensia, Band 6).

Abdallah, Y. (1975): Die Personennamen in al-Hamdānī's al-Iklīl und ihre Parallelen in den altsüdarabischen Inschriften. Ein Beitrag zur jemenitischen Namengebung. Tübingen.

Abū al-Ḥasan, H.. (1997): Qirā'ah li-kitābāt lihyāniyyah min mințaqat al-'Ulā. Maktabat al-malik Fahd al-wațaniyyah. KSA.

Abū al-Ḥasan, Ḥ. (2002): Noqūš lihyāniyyah min mințaqat al- ${ }^{c}$ Ulā. Maktabat al-malik Fahd alwațaniyyah. KSA.

Arbach, M. (2002): Les Noms Propres du Corpus Inscriptionum Semiticarum, Pars quarta Inscriptiones himyariticas et sabaas continens: Inventaire des Inscriptions sudarabique. Tome 7. Paris, Académie des Inscriptions et Belles-Lettres.

Arbach, M. - Schiettecatte, J. (2006): Catalogue des pièces archéologiques et épigraphiques du Jawf au Musée National de Șan ' $\hat{a}$ '. Șan ${ }^{c} \vec{a}$ ', Centre français d'archéologie et de sciences sociales de $\operatorname{San}^{\mathrm{c}} \overline{\mathrm{a}}$.

Arbach, M. - Schiettecatte, J. - al-Hādī, I. (2008): Collection of Funerary Stelae from the Jawf Valley. San ' $\hat{a}$ ' National Museum 3. Șan ${ }^{\mathrm{c}} \overline{\mathrm{a}}$ ', UNESCO-SFD. 
Avanzini, A. (1995): as-Sawdā': inventaire des inscriptions sudarabiques, 4. Paris.

Beeston, A.-Ghul, M.-Müller, W.-Ryckmans, J. (1982): Sabaic Dictionary (English-FrenchArabic). Louvain.

Branden, A. van den (1950): Les inscriptions thamoudéennes. Louvain.

Branden, A. van den (1956): Les text thamoudéenns de Philby. I-II. Louvain (Bibliothéque du Muséon vols 39,41$)$.

Caskel, W. (1966): Ğamharat an-Nasab: Das genealogiche Werk des Hišām ibn Muhammad alKalby. Leiden.

CIH (1889-1932): Corpus Inscriptionum Semiticarum. Pars quarta: Inscriptions Himyariticas et Sabaeas Contines. Paris.

CIS (1950): Corpus Inscriptionum Semiticarum. Pars Quinta: Inscriptiones Saracenicas Continens. Tomus I, Sectio Prima: Inscriptiones Safaiticae. Paris.

Clark, V. (1980): A Study of New Safaitic Inscriptions from Jordan. A Thesis Presented for the Degree of Doctor of Philosophy, Department of Middle Eastern Studies. University of Melbourne.

Corbett, G. (2010): Mapping the Mute Immortals: a Locational and Contextual Analysis of the Thamudic/Hismaic Inscriptions and Rock Drawing from the Wādì Hafìr of Southern Jordan. Chicago.

Frantsouzoff, Serguet (1995): The Inscriptions from the Temples of DHAT HIMYAM at Raybūn. Proceedings of the Seminar for Arabian Studies Vol. 25, pp. 15-28.

Harahsheh, R. (2001): Nuqūšs șafā'iyyah jadīdah min al-bādiyah al-urdunniyyah aš-šamāliyyah aššarqiyyah. Ph.D. Submitted to University of Baghdad, Iraq.

Harding, G. L. (1969): The Safaitic Tribes. Al-Abhäth Vol. 12, pp. 3-25.

Harding, G. L. (1971): An Index and Concordance of Pre-Islamic Arabian Names and Inscriptions. Toronto (Near and Middle East Series 8).

Hayajneh, H. (1998): Die Personennamen in den qatabāniscen Inschriften. Lexikalische un grammatische Analyse im Kontext der semitischen Anthroponomastik. New York.

Hazim, R. (1986): Die safaitischen Theophoren Namen im Rahmen der gemeinsemitschen. Dissertation. Namengebung, Marburg.

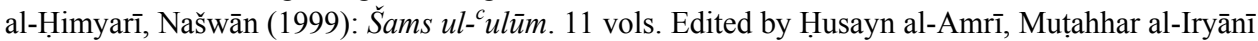
and Yūsuf ${ }^{\mathrm{c}}$ Aballāh. Beirūt.

Hoftijzer, J.-Jongeling, K. (1995): Dictionary of the North-West Semitic Inscriptions. 2 vols. Leiden.

Ibn Durayd, Abū Bakr Moḥammad Ibn al-Ḥasan (1991): Kitāb al-Ǐstiqāq, edited by ${ }^{\mathrm{c}} \mathrm{Abd}$ Al-Salām Hārūn. Beirūt.

Ibn Manẓūr, J. (2003): Lisān al- ${ }^{c}$ arab. 15 vols. Beirūt.

Jamme, A. (1956): Les antiquités sud-arabes du Museo Nazionale Romano. Monumenti antichi Vol. 43, pp. 1-120.

Jamme, A. (1963): The al- 'Uqlah Texts. Washington D.C. (Documentation sud-arabe, 3).

Jamme, A. (1967): Thamudic Studies. Washington D.C.

King, G. (1990): Early North Arabian Thamudic E, A Preliminary Description Based on a New Corpus of Inscriptions from Hisma Desert of Southern Jordan and Published Material. London, University of London.

Littmann, E. (1943): Safaitic Inscriptions. Division IV: Semitic Inscriptions, Section C. Leiden.

Maani, S. (2011): Kitābāt ${ }^{c}$ arabiyah qadīmah min bādiyat $M a^{c} \bar{a} n$. Amman.

Maani, S. - Kareem, J. (2000): Dirāsat nuqūǔs c Arabiyyah šamāliyyah min Wādī al-Ḩašābiyyah fī albādiyah al-urduniyyah al-janoubiyyah al-Šarqiyyah/mințaqat al-Jafr. Majallat Mu'tah lilbuḥūth wal-dirāsāt Vol. 15, No. 5, pp. 219-265. 
Maani, S. - Kareem, J. (2001): Qirā'ah li nuqūš tamūdiyyah jadīdah min 'aqabat alhijāz. Al Manarah Vol. 8, No. 2, pp. 43-84.

Maani, S.-Sadaqah, I. (2002): New Safaitic Inscriptions from al-Mafraq Archaeological Office. Syria 79, pp. 249-269.

Maani, S.-Sadaqah, I. (2003): Two Hismaic Inscriptions from South-Eastern Jordan. Dirasat 3, pp. $643-660$.

Macdonald, M. (2000): Reflection on the Linguistic Map of Pre-Islamic Arabia. Arabian Archaeology and Epigraphy Vol. 11, pp. 28-79.

Macdonald, M. (2004): Ancient North Arabian. In: Woodard, R. D. (ed.): The Cambridge Encyclopedia of the World's Ancient Languages. Cambridge, Cambridge University Press.

Mikyash, A. (1993): Asmā' al-qabā'il fī al-nuqūš al-'arabiyyah al-janūbiyyah. Unpublished MA Thesis. Yarmouk University, Jordan.

Negev, A. (1991): Personal Names in Nabatean Realm. Jerusalem, Institute of Archaeology, The Hebrew University (Qedem 32).

Pirenne, Jacqueline (1975): The Incense Port of Moscha (Khor Rori) in Dhofar. The Journal of Oman Studies 1, pp. 81-96.

Rawan, Schirin (2013): Neue safaitische Inschriften aus Süd-Syrien. Berlin, Shaker Verlag (Semitica et Semitohamitica Berolinensia, Band 16).

RES (1929-1968): Répertoire d'Epigraphie Semitique: publié par la Commission du Corpus Inscriptionum Semiticarum. Paris.

al-Rousan, M. (1987): Al-qabā'il al-tamüdiyyah wa'l-șafawiyyah. King Sa'oud University. KSA.

Sadaqah, I. (2013): Nabataean and the Coinage Gold Minting. In: Khairy, Nabil I. - Weber, Thomas M. (eds): Studies on the Nabataean Culture I. Refereed Proceeding of the International Conference on the Nabataean Culture. Amman, pp. 143-147.

Sadaqah, I.-Harahsheh, R. (2005): Nuqūš șafawiyyah jadīdah min marabb al-ganam šarq aṣșafāwī - al-Bādiyah al-Urduniyyah. Adumatu 12, pp. 45-74.

al-Said, S. (1995): Die Personennamen in den minäischen Inschriften. Wiesbaden, Harrassowitz (Veröffentlichungen der Orientalischen Kommission der Akademie der Wissenschaften und Literatur Mainz 41).

al-Said, S. (2004): Nuqūš tamūdiyyah min Taymā'. Journal of Tourism and Archaeology (King $\mathrm{Sa}^{\mathrm{c}}$ oud University, KSA) Vol. 17, No. 1, pp. 183-255.

Tairan, S. (1992): Die Personennamen in den altsabäischen Inschriften. Hildesheim-Olms (Texte und Studien zur Orientalistik 8).

al-Theeb, S. (2000a): Nuqūš qārāa al-tamūdiyyah bi mințaqat al-Jawf bi al-mamlakah al-'arabiyyah al-sa $a^{c} \bar{u}$ diyyah. Mu'assasat ${ }^{\mathrm{c}} \mathrm{Abd}$ Al-Raḥmān Al-Sudairī. KSA.

al-Theeb, S. (2000b): Dirāsah li-nuqūš țamūdiyyah min Jubbā bi-Hā'il. Maktabat al-malik Fahd alwațaniyyah. KSA.

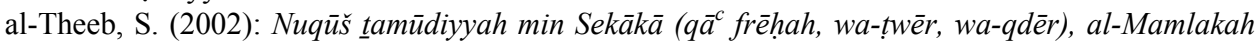
al- ${ }^{c}$ arabiyyah as-sac ${ }^{c}$ diyyah. Maktabat al-malik Fahd al-wațaniyyah. KSA.

al-Theeb, S. (2003): Nuqūš șafawiyyah min šamāl al-mamlakah al- arabiyyah as-sac üdiyyah. Mu'assasat ${ }^{\mathrm{c}} \mathrm{Abd}$ Al-Raḥmān Al-Sudeirī. KSA.

Winnett, F. - Harding, L. (1978): Inscriptions from Fifty Safaitic Cairns. Toronto, University of Toronto Press (Near and Middle East Series 9).

Winnett, F. - Reed, W. (1970): Ancient Records from North Arabia. Toronto, University of Toronto Press (Near and Middle East Series 6).

Winnett, F. - Reed, W. (1973): An Archaeology-Epigraphical Survey of the Hāà'il Area of Northern Sa udi Arabia. Berytus 21, pp. 53-114.

Wuthnow, W. 1930: Die semitischen Menschennamen in griechischen Inschriften und Papyri des Vorderen Orients. Leipzig (Studien zur Epigraphik und Papyruskunde).

al-Zabīdī, Muḥammad Murtậā. (1994): Tãğ al- ${ }^{c}$ arūs min ğawāhir al-qāmūs. 20 vols. Beirūt. 


\section{Photos}

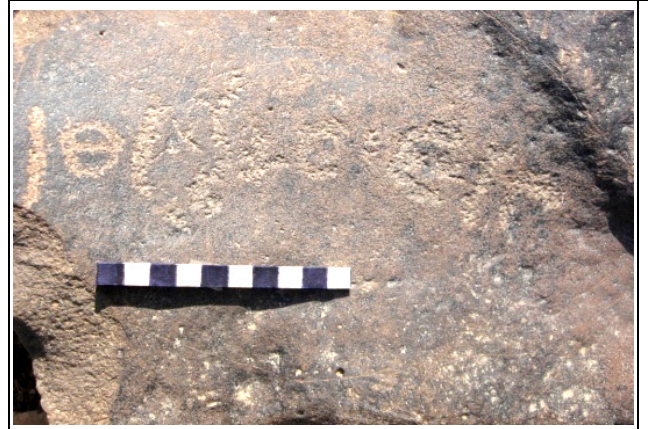

Stone 1, inscription No. 1

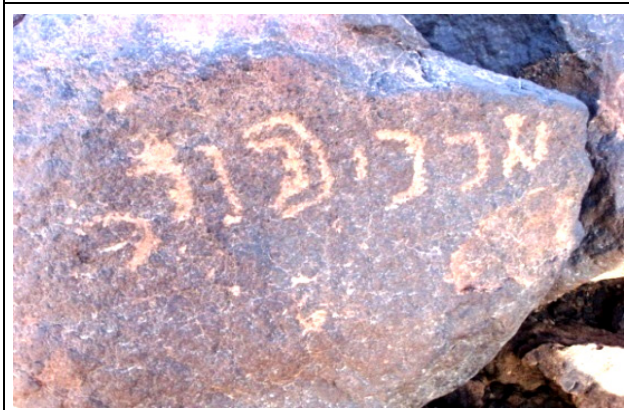

Stone 3, inscription No. 5

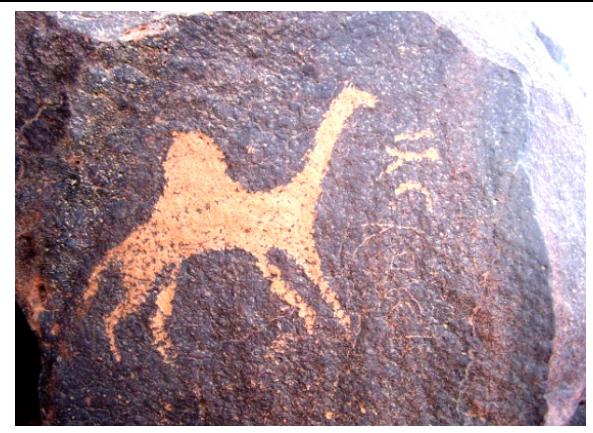

Stone 5, inscription No. 7

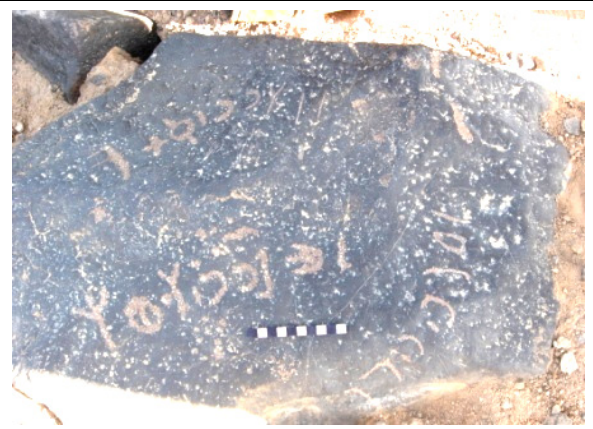

Stone 2, inscriptions Nos 2, 3, 4

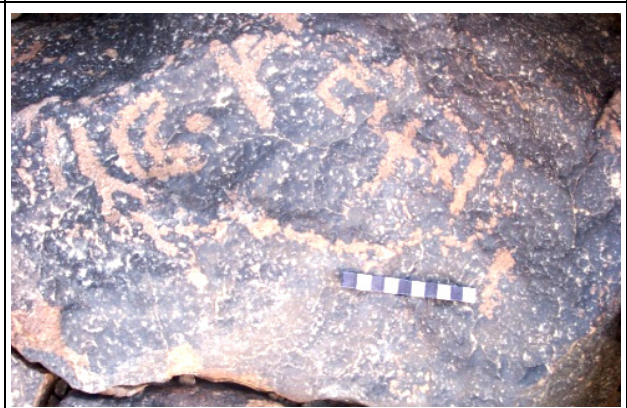

Stone 4, inscription No. 6

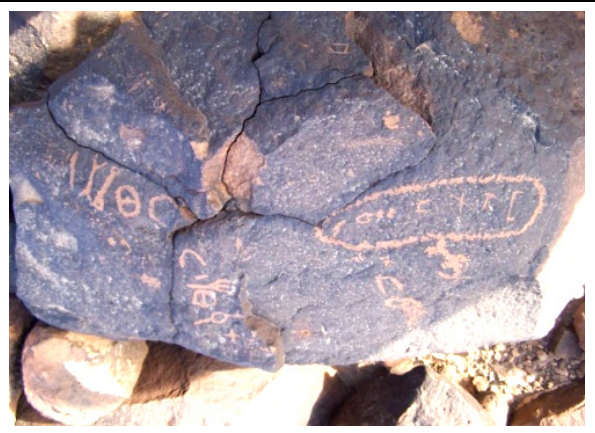

Stone 6, inscriptions Nos 8, 9 


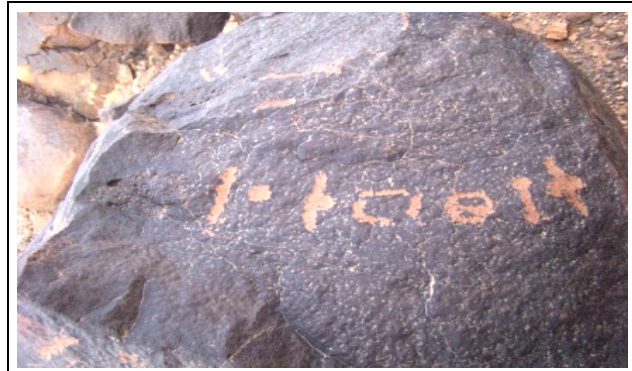

Stone 7, inscription No. 10

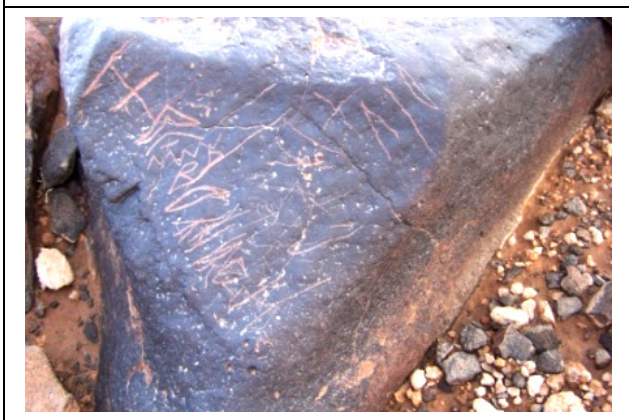

Stone 9, inscription No. 13

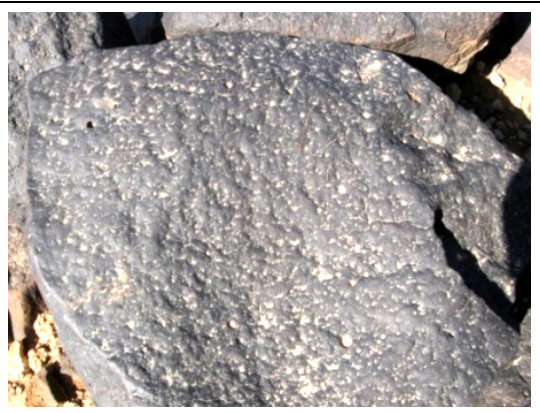

Stone 11, inscription No. 15

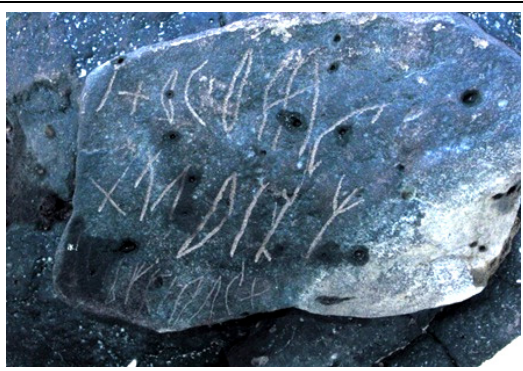

Stone 8, inscriptions Nos 11, 12

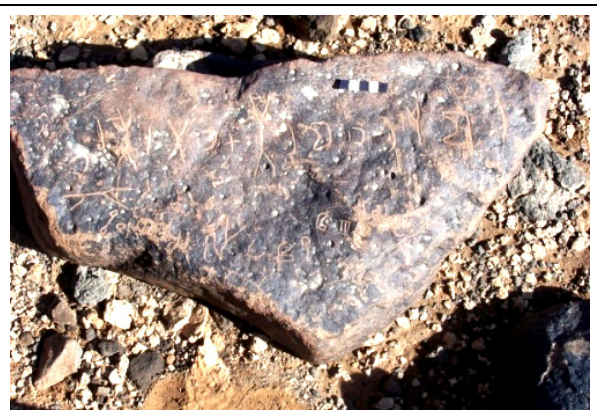

Stone 10, inscription No. 14

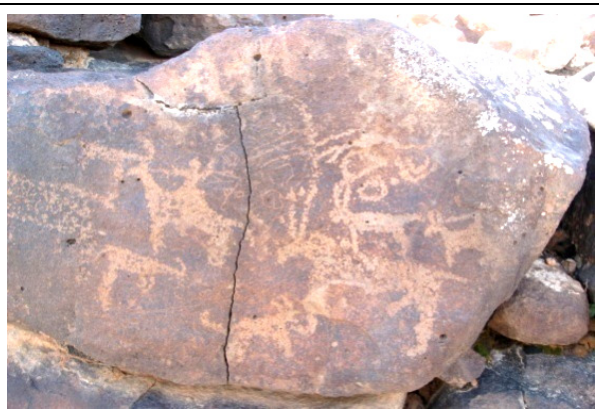

Stone 12, inscription No. 16 